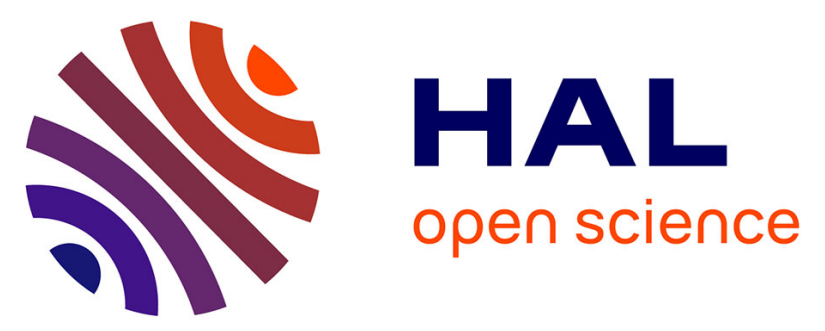

\title{
Sensitivity analysis of the STICS-MACRO model to identify cropping practices reducing pesticides losses
}

Sabine-Karen Lammoglia, David Makowski, Julien Moeys, Eric Justes, Enrique Barriuso, Laure Mamy

\section{- To cite this version:}

Sabine-Karen Lammoglia, David Makowski, Julien Moeys, Eric Justes, Enrique Barriuso, et al.. Sensitivity analysis of the STICS-MACRO model to identify cropping practices reducing pesticides losses. Science of the Total Environment, 2017, 580, pp.117-129. 10.1016/j.scitotenv.2016.10.010 . hal01473466

\author{
HAL Id: hal-01473466 \\ https://hal.science/hal-01473466
}

Submitted on 25 May 2020

HAL is a multi-disciplinary open access archive for the deposit and dissemination of scientific research documents, whether they are published or not. The documents may come from teaching and research institutions in France or abroad, or from public or private research centers.
L'archive ouverte pluridisciplinaire HAL, est destinée au dépôt et à la diffusion de documents scientifiques de niveau recherche, publiés ou non, émanant des établissements d'enseignement et de recherche français ou étrangers, des laboratoires publics ou privés.

\section{(c)(1)}

Distributed under a Creative Commons Attribution| 4.0 International License 


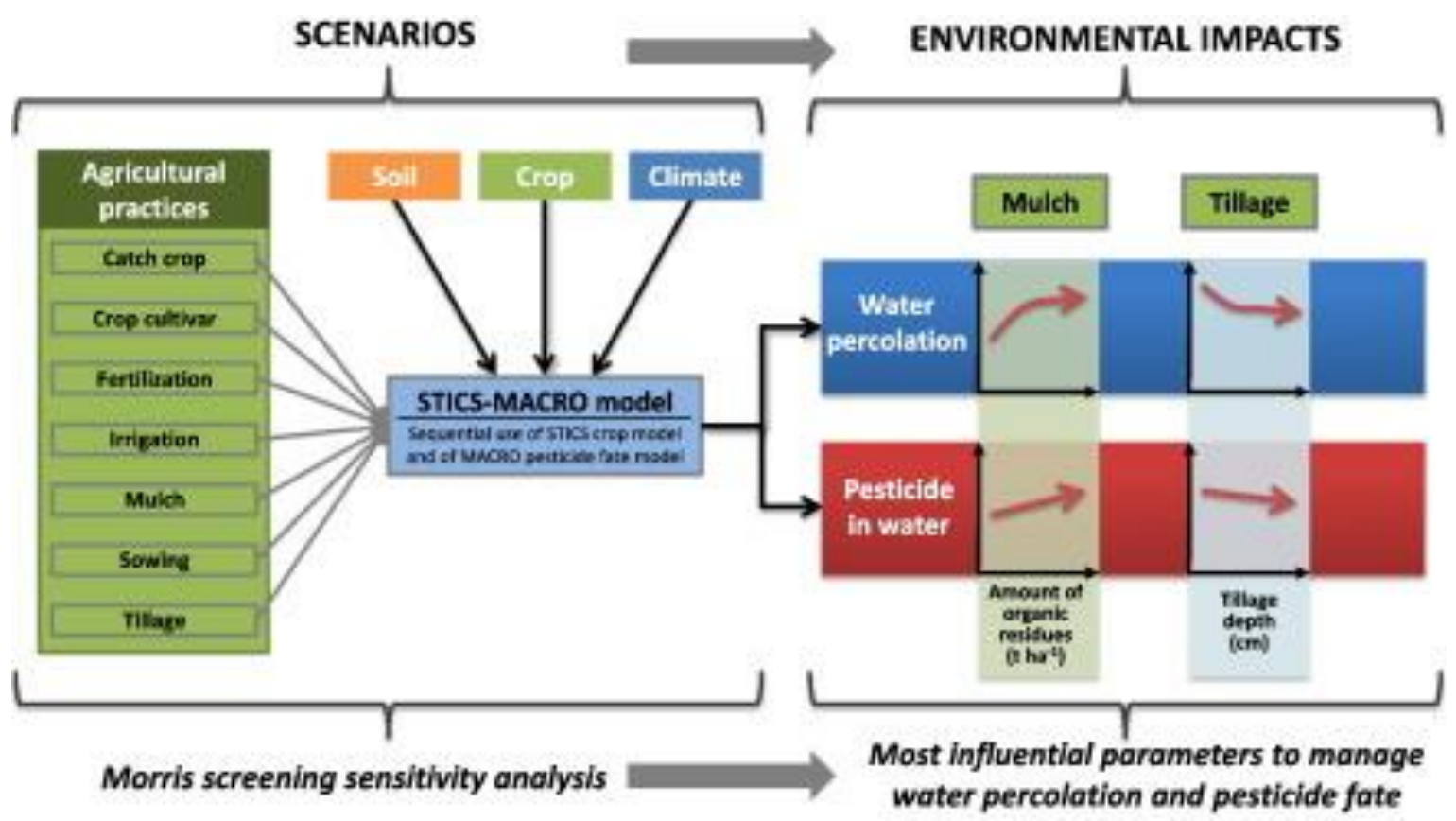

Sabine-Karen Lammoglia, David Makowski, Julien Moeys, Eric Justes, Enrique Barriuso, Laure Mamy

Sensitivity analysis of the STICS-MACRO model to identify cropping practices reducing pesticides losses

Science of The Total Environment, Volume 580, 2017, 117-129

http://dx.doi.org/10.1016/j.scitotenv.2016.10.010 